\title{
ACNE TREATMENT IN PATIENTS WITH CONNECTIVE TISSUE DYSPLASIA
}

\author{
Koshel M. V., Chebotarev V. V.
}

\section{Stavropol State Medical University, Russian Federation}

A cne is a common general term for inflammatory disorders in sebaceous glands and hair follicles. As the respective statistics shows, acne is present in $60-85 \%$ of patients aged $14-18[1,6]$. By the age of 25 the acne severity goes down in $80 \%$ of cases $[2,3,5]$.

Individuals with signs of genetically determined connective tissue dysplasia (CTD) are subject to more severe course and frequent recurrences of acne, which implies a need for additional studies involving patients with acne suffering from connective tissue dystrophy, as well as an idea of modifying the conventional treatment modes.

The purpose of the study is to improve the treatment outcomes in patients with acne who also have connective tissue dysplasia.

Material and Methods. An open prospective longitudinal study was held, which involved 252 acne cases undergoing treatment at the Regional Dermatovenerologic Clinic (Stavropol, Russia), in 2005-2009.

Study inclusion criteria: verified acne diagnisos; CTD symptoms (at least 3 external dysembryogenic stigmas following the diagnostic criteria for CTD); age - above 18 and below 60; patient's awareness and voluntary consent. Study exclusion criteria: systemic therapy with retinoids; antibiotics; topical therapy, or preventive acne treatment at least 60 days prior to the study; participants' voluntary refusal to join the study.

The groups were arranged and based on clinically detected symptoms of CTD. Two groups were made: Group I (126 persons) - patients with acne revealing no CTD symptom; Group II (126 persons) - patients with acne showing CTD symptoms. Sampling was randomized (Group I) and employing the copy-pair method based on the gender and age (Group II).

The clinical examination and diagnostics of the acne cases were done following the clinical practice guidelines for the management of acne (2010). The form of acne was determined trough A. M. Kligman's

Koshel Marina, MD, Assistant, Department of Dermatovenerology and Cosmetology with an Extra Training Programme,

Stavropol State Medical University;

tel.: (8652)287922; e-mail: k010mv1979@mail.ru

Chebotarev Vyacheslav, MD, PhD, Professor, Head of Department of Dermatovenerology and Cosmetology with an Extra Training

Programme, Stavropol State Medical University;

tel.: (8652)287922; e-mail: sgmakvd@mail.ru classification (1994) [4], while the acne severity index (ASI) was calculated based on the American Simplified Disease Severity Index. Counting of various types of follicles was performed with a Dino-Lite Digital microscope AM 311-RO. The size of follicles was evaluated visually for each case detecting the largest and the smallest size in view of the various affected seborrheic skin areas and non-affected ones.

The CTD phenotypic traits were detected based on the National Guidelines for Diagnosing Inherited Disorders of Connective Tissue (2012). The constitutional and morphological types (somatotypes) were assessed within the three-dimensional classification by W. Sheldon.

All the patients underwent blood and urine tests; biochemical blood assay, including the determination of magnesium in plasma and erythrocytes using the diagnostic kit Cormey-Mg-250 (reaction with xylidyl blue in aqueous ethanol).

The treatment strategy relied on the acne severity degree as well as on the stage of the process. The basic treatment scheme in both groups included Junidoks ( 1 pill, twice a day; duration - 14 days); Klenzit Gel topically (applied once, in the night; duration - 1 month); washing with the Cinovit Gel (once per day; afternoon); the Sebium Cream. The patients with acne scoring III-IV within the severity index (ASI) were treated with Roaccutane (0.5-1.0 mg per kilo of body weight; duration - 5-6 months with the dosage to be reduced later on).

Besides, the basic treatment scheme for Group II included magnesium-containing drugs that allowed stimulation of collagen formation: Magnerot (magnesium salt of orotic acid); $3.0 \mathrm{~g}$ per day; duration $-5-6$ months.

The treatment efficiency was assessed with clinical, laboratory, and sociometric evaluation of the patients based on the criteria formulated in conformity with the Clinical practice guidelines for the management of acne (2010). The following efficiency assessment criteria were used - clinical recovery; clinical improvement; lack of change; aggravation. Selection of the efficiency indicators was performed in view of the methodological guidelines of the International Congress on Harmonization of Clinical Study Evaluations. The efficiency was evaluated through the variation method as a share of patients in the selected population where clinical recovery or clinical improvement was registered following the criteria applied. 
The mathematical processing of the data was done using the standard packages of the applied software Statistica 7.0 и SPSS 16.0 for Windows.

Results and Discussion. The analysis of acne cases distribution by types of the disease showed significant differences in their structure within the groups studied. Group I patients were typically affected with the types of acne that correspond the initial degrees of severity while in Group II the prevalent types of the disease were those that come along with a high degree of severity. Given that, the acne cases with CTD had II and III acne severity degrees prevailing (just like it was in Group I). The patients with the number of stigmas ranging from 3 to 5 had ASI I and ASI II ( 13 and $45 \%$ ), while in the cases with the number of stigmas exceeding 5 the ASI was III and IV (15 and $11 \%$ ) The correlation analysis revealed a strong dependency between the CTD intensity and the severity of the disease $(r=-0.3-0.6$, $\mathrm{p}<0.05)$. There was an increase in the number of stigmas detected in the patients with acne, which grew along with an increase in the disease severity.

The levels of Magnesium ions found in the plasma and erythrocytes showed a significant difference when the two groups were compared $(p<0.05)$. Magnesium deficiency in plasma was verified in 68 (54\%) of Group II patients; Magnesium deficiency in erythrocytes (hypomagnesehistya) - in 43 (57\%) patients while the patients with acne in Group I had the same index within norm close to that of a healthy person. (norm $-0.7-1.1 \mathrm{mmol} / \mathrm{l})$. The CTD test sensitivity on blood Magnesium deficiency in the patients with acne was SE 0.54, and its specificity - SP 0.8. At the same time, the likelihood ratio for the positive result was $\mathrm{LR}=2.7$.

Thus, patients with acne associated with CTD reveal (reliably more frequently, if compared to a comparison group of patients; based on likelihood ratio for the positive result) reduced levels of blood magnesium ions. The high likelihood ratio gives evidence that the blood magnesium level is a highly informative laboratory criterion in terms of differential diagnostics of patients with acne associated with CTD.

It was found that the correlation between the level of magnesium in blood plasma $(r=0.38, p<0.05)$ and in erythrocytes $(r=-0.442 p<0.05)$ was high, and went up along with the severity of acne up to the $r=-0.672$ and $r=-0.759$ respectively.

Given the basic medication therapy, the patients with acne in both groups showed a serious decrease in the number of complaints. No significant difference was found in the dynamics of complaints in the two groups, which is proof of a proper basic medication treatment. The two groups of patients with acne showed different dynamics in the number of inflammatory elements (Fig.). The patients in Group I had their papulae and pustules going down in the number faster than those in Group II, and by the end of Week 3 they demonstrated significant difference $(p<0.05)$, which remained there for three weeks. However, by the end of the treatment (Week 8) the two groups showed equal number of unresolved skin elements.

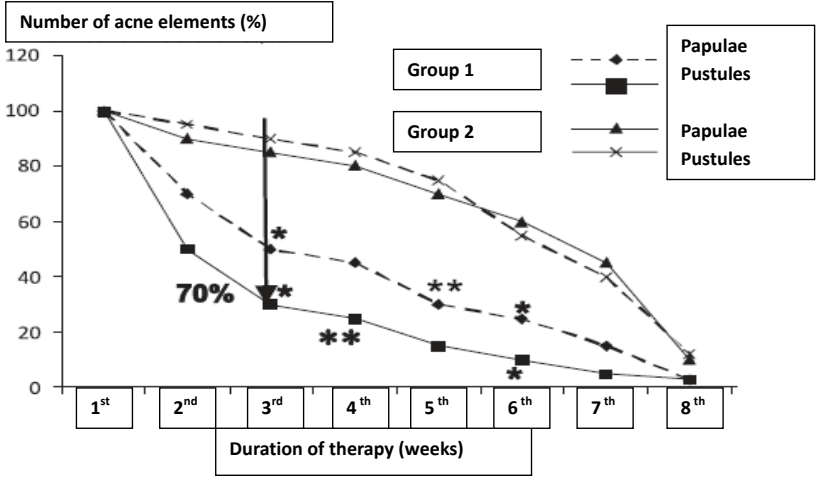

Comparison between the groups ${ }^{\star} p<0,05,{ }^{* *} p<0,01$.

Fig. Dynamics of Inflammatory elements in patients with acne

After the treatment, plasma magnesium deficiency was verified in $13(10 \%)$ patients, while erythrocyte magnesium deficiency - in $18(14 \%)$ of the acne cases with CTD. The difference between the initial and final levels of magnesium in Group II was significant $(p<0.05)$. In Group I the patients had their blood magnesium level within the normal reference index.

Following the treatment no patient demonstrated aggravation in the condition. The population studied had no patient without response to the given treatment. Clinical recovery was shown more often in Group I if compared to Group II. The efficiency of treating patients with acne was $91 \%$, while the same indicator for acne cases with CTD was $86 \%$; besides, there was a stable tendency found towards a reduced efficiency as the number of dysembryogenesis stigmas was growing.

The remote outcomes were evaluated based on the relapse time.

In Group II, unlike in Group I, relapses occurred more often (69\% of the patients) in the first year after the therapy; yet later on those were less frequent. Thus, Group II had significantly higher number of relapses compared to Group I, which ex juvantibus shows the negative impact that connective tissue dysplasia has on the course of acne.

All the treatment schemes employed were safe for the patients with acne vulgaris and connective tissue dysplasia, all this proving the validity of their practical application.

The nature of the major factors associations for acne progress, which was detected through the method of linear regression, proved monotonic, this allowing detecting (with stepwise logistic regression and odds ratio calculation) the most relevant factors for the disease progress: duration of the disease (factorial weight 3.86), concomitant pathology (2.67), somatotype (3.71), magnesium deficiency in erythrocytes $(6,91)$ and plasma $(6,37)$, as well as phenotypic signs of CTD (dysembryogenic stigmas) (6.89). The index of the relative risk for acne development in the presence of the significant factors for disease progress depended on the disease duration ( $>3 \mathrm{yrs}$ ), hypomagnesehistya, hypomagnesemia, the somatotype, the number of CTD stigmas exceeding 5 (0.1-10).

The statistical model included quantitative variables - the level of magnesium in blood serum (X1) and 
in erythrocytes (X2), and a categorical variables - the phenotypic signs of CTD (X3), for which dichotomous values were used ( 0 - sign absent, 1 - sign present).

The Table offers the parameters of the model describing the probability of efficient acne therapy dependent on the CTD intensity.

Parameters of prediction model for efficient therapy of acne

\begin{tabular}{|c|c|c|c|c|}
\hline Parameters & $\begin{array}{l}\text { Estimated } \\
\text { coefficient }\end{array}$ & $\begin{array}{c}\text { Standard } \\
\text { error }\end{array}$ & $x^{2}$ & $\begin{array}{c}\text { Significance } \\
\text { level }\end{array}$ \\
\hline $\begin{array}{l}\text { Level of } \\
\text { Magnesium in } \\
\text { blood plasma }\end{array}$ & 2.648 & 0.789 & 8.489 & 0.0047 \\
\hline $\begin{array}{l}\text { Level of } \\
\text { Magnesium in } \\
\text { erythrocytes }\end{array}$ & 6.159 & 4.484 & 3.591 & 0.0217 \\
\hline $\mathrm{CTD}=0$ & -3.776 & 1.726 & \multirow{2}{*}{29.715} & \multirow{2}{*}{0.0024} \\
\hline $\mathrm{CTD}=1$ & 6.371 & 0.155 & & \\
\hline Remission $=0$ & -3.702 & 1.155 & \multirow{2}{*}{37.708} & \multirow{2}{*}{0.0001} \\
\hline Remission $=1$ & 2.354 & 1.627 & & \\
\hline
\end{tabular}

In view of the criteria identified, the regression equation for calculating the efficiency of acne therapy shall be as follows:

Prob (event) $=\exp ($ eta $) /(1+\exp \quad$ (eta)), where Prob (event) is the probability of efficient acne therapy, eta $=2,648$ * X1 $6,159{ }^{*} \mathrm{X} 2+6,371 * \mathrm{X} 3$

\section{References}

1. Adaskevich V. P. Acne and rosacea. SPb.: «Olga»; 2000. $132 \mathrm{p}$.

2. Kubanova A. A. Prospective Development for Dermatovenerology Service in Russian Federation. Volume of I All-Rus. Congr. of Dermatovenerologists. SPb.; 2003. P. 12-18.

3. Potekaev N. N. Acne and rosacea. M.: «Binom. Laboratory of Knowledge»; 2007. $216 p$

\section{ACNE TREATMENT IN PATIENTS WITH CONNECTIVE TISSUE DYSPLASIA \\ KOSHEL M. V., CHEBOTAREV V. V.}

262 patients with acne were examined, 156 of them also showing signs of connective tissue dysplasia (CTD). The laboratory studies included a complete blood count and urinalysis, a biochemical blood test, including the determination of magnesium in plasma and erythrocytes with the diagnostic kit CormeyMg-250 (reaction with xylidyl blue in aqueous ethanol). The patients were treated with drugs in view of the clinical practice guidelines for this pathology. The study has shown that the patients with acne and CTD had reduced magnesium ions level in blood (compared to the other group); they had a more severe acne course, with the relapses occurring earlier following the treatment.

Due to this, the basic treatment scheme for patients with connective tissue dysplasia included magnesium-containing medications stimulating collagen formation. A mathematical analysis was run to detect the negative impact CTD has on the course and treatment of acne, which offered a reliable explanation to the algorithm of treating acne cases associated with CTD, as well as allowed demonstrating the relevance of magnesium-containing drugs.

Key words: acne, connective tissue dysplasia, reduction of magnesium where Prob (event) is acne treatment efficiency, exp - the function corresponding to the number «e» (2.71), raised to the power that is equal to the result of the calculation within brackets; $\mathrm{X} 1-\mathrm{X} 3$ - variables describing the presence of CTD signs and the level of magnesium in blood and in erythrocytes. In the event the value calculated works for 1.0 , the probability of efficient treatment in these patients goes down significantly.

The data of the mathematical analysis for observing the negative impact that CTD has on the course and efficiency of acne therapy allow a rationale for the treatment algorithm for patients suffering from acne associated with CTD.

Conclusion. The efficiency of medication therapy for acne cases with connective tissue dysplasia is $86 \%$, and it is going down monotonically along with an increase in the dysembryogenic stigmas number. The combination of magnesiumcontaining drugs with the basic medication therapy helps improve the clinical condition, which is seen through a significant regress in the acne clinical symptoms, recovered levels of magnesium ions in the blood, and a better life quality for patients with acne suffering from connective tissue dysplasia.

4. Plewig G., Kligman A. A. Acne and Rosacea. Berlin: «Springer»; 1994. $740 \mathrm{p}$.

5. Purdy S., de Berker. D. Acne. B.M.J. 2006;333(7575):949953.

6. Webster G. F. Acne vulgaris. B.M.J. 2002:325(7362):475479.

\section{АЕЧЕНИЕ АКНЕ У ПАЦИЕНТОВ С АИСПААЗИЕЙ СОЕАИНИТЕАЬНОЙ ТКАНИ \\ М. В. КОШЕАЬ, В. В. ЧЕБОТАРЕВ}

Обследовано 262 пациента с акне, у 156 из которых были также выявлены признаки дисплазии соединительной ткани. Лабораторные методы исследований включали, в том числе определение магния в плазме крови и эритроцитах при помощи диагностического набора Cormey-Mg-250 (реакция с ксилидиловым голубым в водном растворе этанола). Пациентам проводилось лечение с учетом клинических рекомендаций по данной патологии. Показано, что у больных акне, ассоциированной с ДСТ, достоверно чаще, чем у больных группы сравнения, встречается снижение содержания ионов магния в крови, более тяжелое течение акне, а после курса лечения рецидив наступал раньше. В связи с этим в базовую схему лечения больных с дисплазией соединительной ткани включали препараты, содержащие магний и позволявшие стимулировать коллагенообразование. Проведен математический анализ учета неблагоприятного влияния ДСТ на течение и эффективность терапии акне, что позволило обосновать алгоритм ведения пациентов с акне, ассоциированной с ДСТ, и показать значимость применения магнийсодержащих препаратов.

Ключевые слова: акне, дисплазия соединительной ткани, снижение содержания магния 